Supplement of

\title{
Influence of urban pollution on the production of organic particulate matter from isoprene epoxydiols in central Amazonia
}

Suzane S. de Sá et al.

Correspondence to: Scot T. Martin (scot_martin@harvard.edu)

The copyright of individual parts of the supplement might differ from the CC BY 3.0 License. 


\section{S1. Instrumentation}

\section{S1.1 Aerosol Mass Spectrometry: set up and operation}

Online measurements of organic and sulfate mass concentrations measured in this study

4 were made by a High-Resolution Time-of-Flight Aerosol Mass Spectrometer (AMS, Aerodyne

5 Research Inc.) (DeCarlo et al., 2006; Canagaratna et al., 2007). The AMS provided real-time

6 measurements of bulk non-refractory particle chemical composition (organic, sulfate, nitrate,

7 ammonium, chloride) and chemically resolved mass-diameter distribution. Air was sampled

8 through a critical orifice and enters an aerodynamic lens, which focused the submicron particles

9 into a narrow beam (Zhang et al., 2004). Particles traveled through a sizing chamber to reach a

10 porous tungsten inverted-cone vaporizer at $600^{\circ} \mathrm{C}$, and non-refractory components volatilized.

11 The gaseous molecules were then ionized through electron impact $(70 \mathrm{eV})$, and the ions were

12 measured by time-of-flight mass spectrometry. The high mass resolution allowed for the

13 distinction of ions having the same nominal mass but different elemental composition. Data

14 analysis was performed using standard AMS software (SQUIRREL 1.56D, PIKA 1.14G)

15 (webpage: http://cires1.colorado.edu/jimenez-

16 group/ToFAMSResources/ToFSoftware/index.html).

Aerosol particles were sampled through a cyclone (URG-2000-30EH) which had a size

18 cut of $2.5 \mathrm{um}$ for a flow of $16.7 \mathrm{~L} \mathrm{~min}^{-1}$. The sampled flow (14.9 to $\left.16.3 \mathrm{~L} \mathrm{~min}^{-1}\right)$ traveled

19 through a stainless steel tube for about $1.5 \mathrm{~m}$. The flow was then split in two: a 4-m line for

20 sampling $\left(1.2\right.$ or $\left.2.6 \mathrm{~L} \mathrm{~min}^{-1}\right)$ and a line $\left(13.7 \mathrm{~L} \mathrm{~min}^{-1}\right)$ for exhaust. The sampling flow changed

21 between 1.2 and $2.6 \mathrm{~L} \mathrm{~min}^{-1}$ according to the flow set up of the Scanning Mobility Particle Sizer

22 (SMPS), which was sampling in parallel to the AMS. The sampling flow then entered a poly-

23 tube Nafion dryer (Perma Pure, model PD-100T). Drying prior to entering the instrument 
24 container aimed at avoiding water condensation in the line inside the container, which was

25 always kept at lower temperatures than outside (i.e., trailer temperature was around $23{ }^{\circ} \mathrm{C}$ during

26 daytime). RH measured after the poly-tube dryer and inside the container was at 40 to $80 \%$.

27 Within the container, a subflow $\left(0.6\right.$ or $\left.3 \mathrm{~L} \mathrm{~min}^{-1}\right)$ was passed through a mono-tube Nafion dryer

28 (Perma Pure, model MD-110) to reach $\mathrm{RH}<40 \%$. A flow of $0.09 \mathrm{~L} \mathrm{~min}^{-1}$ was sampled by the

29 AMS, and the remaining flow of 0.5 or $2.9 \mathrm{~L} \mathrm{~min}^{-1}$ was sampled by the SMPS. The ambient air

30 sampling line was integrated to a valve switching system, which alternated the AMS/SMPS

31 sampling between the unprocessed ambient air and air processed by oxidation flow reactors or a

32 thermal denuder. The unprocessed ambient air (used for this analysis) was sampled for 4 out of 8

33 min, constituting half of the total acquired data set.

34 Due to expected low mass concentrations and to secondary need for the low-sensitivity

35 high-resolution data, the AMS was operated for most of the time in medium-resolution V-mode

$36(\Delta m / m=2200$ at $m / z 44)$, which was used for mass quantification. High-resolution W-mode

$37(\Delta m / m=4000$ at $m / z 44)$ was acquired for one of every six days. These data were used to aid

38 choice of ions to fit. When only V-mode data were acquired, the instrument was operated in

39 "mass spectrum" sub-mode for $180 \mathrm{~s}$ and in "particle-time-of-flight" sub-mode for $60 \mathrm{~s}$. When

40 W-mode data were also collected, the "W-mass-spectrum" sub-mode was operated for $60 \mathrm{~s}$, the

41 "V-mass-spectrum" sub-mode ran for $120 \mathrm{~s}$, and "V-particle-time-of-flight" sub-mode ran for 60

42 s. Both ways of operation corresponded to 4 min for each cycle, allowing for synchronization to

43 the valve switching system.

44 The AMS sensitivity and the ammonium relative ionization efficiency (RIE) were

45 calibrated every five days using dried ammonium nitrate particles having a mobility diameter of

$46400 \mathrm{~nm}$. An interpolated curve of the obtained values, corresponding to RIE $=4.3 \pm 0.2$, was 
47 used for mass calculation corrections. The sulfate RIE was calibrated using ammonium sulfate a

48 few times during the campaign, and the average value of $0.9 \pm 0.1$ was applied to the entire

49 campaign. The collection efficiency (CE) was determined as 1.0 for IOP1 according to volume

50 comparison to the two co-located Scanning Mobility Particle Sizers (Figure S6). Volume of

51 black carbon (BC) accounted for $8 \pm 6 \%$ of the total volume measured by SMPS, for an

52 assumed density of $1.8 \mathrm{~g} \mathrm{~cm}^{-3}$ for BC. Since BC data were limited, the abscissa of Figure S6 was

53 not subtracted by BC contribution. This CE value was consistent with that used for the AMAZE-

5408 in the wet season of 2008 (Chen et al., 2009).

55 S1.2 Semi-Volatile Thermal desorption Aerosol Gas Chromatography: set up and 56 operation

57 Online measurements of organic tracer compounds in the particle and gas phases were 58 made by a Semi-Volatile Thermal desorption Aerosol Gas chromatograph (SV-TAG). This

59 instrument is described in detail elsewhere (Isaacman et al., 2014). Its operation is briefly

60 presented here.

Air was sampled at $20 \mathrm{~L} \mathrm{~min}^{-1}$ from the center stream of a flow of $200 \mathrm{~L} \mathrm{~min}^{-1}$ through a

$62 \quad 15.24 \mathrm{~cm}(\mathrm{OD})$ stainless steel duct at a height of approximately $5 \mathrm{~m}$ above ground level. The

63 flow was then divided into two channels, passing through a PM1 cyclone at $10 \mathrm{~L} \mathrm{~min}^{-1}$, each

64 containing a custom Filter Collection and Thermal Desorption cell (F-CTD). The F-CTD

65 quantitatively collected and retained both particle- and gas-phase compounds. A multi-channel

66 carbon denuder (MAST Carbon) was used to remove all gases upstream of one collection cell. In

67 this way, two samples were simultaneously collected: a "particle" sample and a "total" gas-plus-

68 particle sample. Samples were thermally desorbed from the cells subjected to a ramping

69 temperature from 30 to $310{ }^{\circ} \mathrm{C}\left(35^{\circ} \mathrm{C} \mathrm{min}{ }^{-1}\right)$ into a helium stream that was $80 \%$ saturated with 
70 MSTFA (N-Methyl-N-(trimethylsilyl) trifluoroacetamide). Hydroxyl groups were converted into

71 silyl esters and ethers. Analytes were transferred to the GC column, and the sample was analyzed

72 through a commercially available GC/MS (7890A/5975C; Agilent Technologies). The

73 chromatographic data were analyzed using the publicly available software TAG ExploreR and

74 iNtegration (Isaacman-VanWertz and Sueper).

75 Compounds were quantified using isotopically labeled internal standards to correct for

76 run-to-run variability in sample transfer efficiency and instrument response. Regular multi-point

77 calibrations were made of approximately 100 authentic standards. Pentaerythritol-2- ${ }^{13} \mathrm{C}$ was used

78 for 2-methyltetrols and $\mathrm{C}_{5}$-alkene triols. The uncertainty in mass concentration was

79 approximately 15\% (Isaacman et al., 2014). $\mathrm{C}_{5}$-alkene triols were quantified using the calibration

80 factor of 2-methyltetrols under the assumption of an identical total ion response. An absence of

81 an authentic standard results in unconstrained uncertainty in mass concentration of 30 of $50 \%$

82 (Jaoui et al., 2005).

\section{$83 \quad \mathrm{S1.3} \mathrm{NO}_{y}$ measurements}

84 The $\mathrm{NO}_{y}$ measured included the following species: $\mathrm{NO}, \mathrm{NO}_{2}, \mathrm{HNO}_{3}$, particle nitrate,

$85 \mathrm{RNO}_{3}$, and PAN. Measurements were made by a custom analyzer designed by Air Quality

86 Design (AQD; http://www.airqualitydesign.com). The analyzer was based on two commercial

87 oxides of nitrogen detectors made by Thermo Scientific (Model 42i TLE) and extensively

88 modified by AQD. An external, temperature-controlled inlet box was mounted at $10 \mathrm{~m}$ above

89 ground level.

90 The instrument contained both a research grade LED photolysis cell for converting $\mathrm{NO}_{2}$

91 into $\mathrm{NO}$ and a heated molybdenum converter for converting total $\mathrm{NO}_{y}$ into NO. One channel,

92 leading from the photolysis cell to one 42i TLE detector, alternated every minute between NO 
93 and $\mathrm{NO}_{x}$ by switching the LED photoloysis cell on/off. The other channel, leading from the

94 molybdenum converter to the second 42i TLE detector, measured total $\mathrm{NO}_{y}$. The detectors

95 internally measured zero based on pre-reaction of the sample with ozone. Instrument response

96 was measured by addition of NO in zero air at the sampling point $(10 \mathrm{~m})$. Converter efficiency

97 was measured by gas-phase titration of the $\mathrm{NO}$ standard to $\mathrm{NO}_{2}$. An $\mathrm{HNO}_{3}$ source was sampled

98 every other day. The calibration unit was a Thermo Scientific Model 146i calibrator equipped

99 with gas-phase titration and a permeation oven. The raw $\mathrm{NO}_{y}$ measurements, reported at a

100 resolution of $10 \mathrm{~s}$, were averaged into bins of $30 \mathrm{~min}$ to filter for local events not representative

101 of the larger scale chemical processes that form the scope of this study.

102 S2. Positive Matrix Factorization and the IEPOX-SOA factor

103 The time series of mass spectra of organic material measured by the AMS was analyzed

104 by positive matrix factorization (PMF) using a standard analysis toolkit (Ulbrich et al., 2009).

105 High-resolution, V-mode data were used. The PMF solution was based on minimization of the

106 "Q-value" or "PMF quality-of fit parameter", meaning the sum of the weighed squared residuals

107 for a chosen number of factors. The interpretation of the physical significance of the AMS PMF

108 factors took into account correlations with quantities simultaneously measured by other

109 instruments. The solution consisted of six factors, and the present study focuses on one of the

110 derived factors, labeled "IEPOX-SOA". de Sá (in preparation) focuses on presentation of the

111 other factors.

112 The profile of the resolved IEPOX-SOA factor is shown in Figure S1. A key

113 characteristic is intensity at $\mathrm{C}_{5} \mathrm{H}_{6} \mathrm{O}^{+}(\mathrm{m} / \mathrm{z}$ 82) (Hu et al., 2015). In addition, a prominent signal at

$114 \mathrm{C}_{4} \mathrm{H}_{5}{ }^{+}(\mathrm{m} / \mathrm{z} 53)$ is observed, which has also been reported as characteristic of the IEPOX-SOA

115 factor (Hu et al., 2015). The IEPOX-SOA factor is also relatively highly oxidized, as expressed 
116 by $f_{44}=0.15$ and oxygen to carbon atomic ratio $\mathrm{O}: \mathrm{C}=0.80$, applying the calibration described in 117 Canagaratna et al. (2015).

118 Technical diagnostics of the six-factor solution are presented in Figure S2 and more 119 extensively described in (de Sá, in preparation). Panel b shows the quality of fit parameter $120 Q / Q_{\text {expected }}$ (Ulbrich et al., 2009) as a function of the number of factors, suggesting that the 121 solution should have at least three factors. Panel a shows a great reduction in the structure of the 122 total residuals when going from the five-factor to the six-factor solution. The six-factor solution 123 also offered more meaningful factor profiles ("mass spectra”) (de Sá, in preparation). Panel c 124 shows $Q / Q_{\text {expected }}$ as a function of the rotational ambiguity parameter $f_{\text {peak }}$ (Ulbrich et al., 2009) 125 for the six-factor solution. A plausible range for $f_{\text {peak }}$ was determined according to the best 126 practice of limiting $Q / Q_{\text {expected }}$ to a value that does not exceed $0.1 \%$ of the minimum value 127 (occurring at $f_{\text {peak }}=0$ ). The default value of $f_{\text {peak }}=0$ was chosen for the final six-factor solution, 128 since no significant improvements in the external validation of the factors were observed.

129 Moreover, the IEPOX-SOA factor resolved in the six-factor solution had a very robust time trend 130 across a range of rotations in the solution (Figure S2d). As $f_{\text {peak }}$ varied, the correlation of factor 131 loading with C5-alkene triols concentrations remained approximately constant, even as some 132 features of the factor profile changed significantly, such as the relative signals of $\mathrm{C}_{5} \mathrm{H}_{6} \mathrm{O}^{+}$and $133 \mathrm{CO}_{2}{ }^{+}$, respectively $f\left(\mathrm{C}_{5} \mathrm{H}_{6} \mathrm{O}\right)$ and $f\left(\mathrm{CO}_{2}\right)$, as well as the magnitude of factor loadings and 134 consequently the ratio $f$.

135 The loading of the IEPOX-SOA factor may be an overestimate or an underestimate of the 136 atmospheric concentration of the IEPOX-derived PM (brown dashed lines in Figure 1). In 137 respect to overestimate, the AMS mass spectrum observed in laboratory studies for the uptake of 138 IEPOX by acidic sulfate particles is statistically equal to that obtained for the uptake of isoprene 
139 photo-oxidation products, yet IEPOX accounted for only half of those products (Liu et al., 2015).

140 The implication is that the uptake of non-IEPOX species can lead to a similar AMS spectrum.

141 Pathways of PM production from condensation of multifunctional hydroperoxides lead to a

142 distinct mass spectrum from IEPOX pathways, and are not expected to be highly active under the

143 acidic particle conditions of these experiments (Riva et al., 2016), leaving a large mass fraction

144 of produced PM unexplained. The combination of AMS vaporization at $600{ }^{\circ} \mathrm{C}$ and ionization by

145 electron impact at $70 \mathrm{eV}$ may convert IEPOX-derived and non-IEPOX-derived molecules into

146 similar groups of ions, which then give rise to a similar mass spectrum. The SV-TAG, which

147 uses desorption temperatures up to $310^{\circ} \mathrm{C}$ and thus can also induce thermal decomposition of

148 some molecules, might also result in an in-common analyte (i.e., tracer) between IEPOX-derived

149 and non-IEPOX-derived molecules, thereby precluding a constraint on any possible overestimate

150 by the AMS factor (Isaacman-VanWertz et al., 2016; Lopez-Hilfiker et al., 2016). For these

151 reasons, the loading of the IEPOX-SOA factor might overestimate IEPOX-derived PM

152 concentrations by accounting for other isoprene oxidation products that are not produced through

153 the IEPOX intermediate.

154 In respect to underestimate, the loading of the IEPOX-SOA factor may not capture the

155 entire particle-phase carbon footprint that originated from IEPOX uptake. Extensive atmospheric

156 processing, such as reactions with hydroxyl radicals or photolysis, can partly eliminate the initial

157 products of IEPOX uptake (Kroll et al., 2009; Bateman et al., 2011; Epstein et al., 2014; Hu et

158 al., 2015; Hu et al., 2016). The IEPOX-originated carbon can still be inside the particle, yet it no

159 longer contributes to the loading of the IEPOX-SOA factor because of an altered mass spectrum

160 for some molecules. Atmospheric reactions gradually homogenize particle composition and

161 properties, and the AMS spectra can become more uniform (Jimenez et al., 2009). Specifically, 
162 the ratio of signal intensity at $\mathrm{m} / \mathrm{z} 44$ to that at $\mathrm{m} / \mathrm{z} 43$ increases, and the relative intensity of $\mathrm{m} / \mathrm{z}$

16382 decreases (Ng et al., 2011; Hu et al., 2015). This modified organic material, which originally

164 entered the particle phase through IEPOX uptake, may then contribute to the loading of PMF

165 factors other than IEPOX-SOA, such as the oxidized organic factors broadly labeled as "OOA"

166 (Zhang et al., 2005). For these several reasons, the IEPOX-SOA factor loading might be an

167 underestimate of IEPOX-derived PM concentrations.

168 S3. Comparison of background and polluted cases

169 The presence of a pollution plume at T3 is indicated by a combination of several external

170 measured variables, including particle number, ozone, and $\mathrm{NO}_{y}$ concentrations. The definition of

171 background and polluted cases aimed at selecting afternoons that were associated with extreme

172 values of those variables. Conditions entailing concentration of ozone at around $10 \mathrm{ppb}$ or less,

173 particle number concentration of less than $500 \mathrm{~cm}^{-3}$, and $\mathrm{NO}_{y}$ concentrations of less than $1 \mathrm{ppb}$

174 were collectively a strong indicative of a background case. Conditions including ozone

175 concentrations upward of $30 \mathrm{ppb}$, particle number concentration above $2000 \mathrm{~cm}^{-3}$, and $\mathrm{NO}_{y}$

176 concentrations around $1.5 \mathrm{ppb}$ or above indicated pollution. Measurements of these variables

177 onboard the G-1 aircraft confirmed what the ground measurements suggested on the several days

178 that the G-1 flew overhead.

179 Examples of these supporting data are illustrated in Figure 3 for the chosen background

180 and polluted days (March 3 and 13, 2014, respectively) composing the primary case study

181 analyzed in the main text. A few other afternoons, representative of these two extremes of

182 background and polluted cases, were selected from the campaign time series and are depicted in

183 Figure S4. The top panel shows cases of background conditions, and the bottom panel shows

184 cases of polluted conditions. The local wind direction observed for the polluted cases generally 
185 characterized by easterlies, as consistent with Manaus direction, whereas for the background

186 cases it tends to diverge from that prevailing direction. The cases within each category are

187 ordered from left to right in ascending order of IEPOX-SOA factor loadings.

188 Sulfate concentrations had a wide range of values, even for background conditions

189 (Figure S4), as discussed in the main text. Meteorological conditions such as overcast (lower

190 photoxidation activity) and rain events (higher wet deposition), as seen on March 20 and March

19123 , are some of the factors that control particle number and mass concentration (sulfate and

192 organic compounds). These factors help to explain the natural variability in sulfate mass

193 concentration. By comparison, on a sunny day, with winds mostly coming from the northeast

194 direction, as exemplified by February 16 and March 3, sulfate mass concentrations can be around

$1950.3 \mu \mathrm{g} \mathrm{m}^{-3}$ or more, values which are also typical of some polluted days (bottom panel). Both the 196 factor loading and the ratio $f$ increased with increasing sulfate (rows 2 and 3 of top panel), when $197 \mathrm{NO}_{y}$ levels were approximately the same. A comparison of February 16 and March 3 shows in 198 addition the importance of $\mathrm{NO}_{y}$ concentration: for similar concentrations of sulfate and organic $199 \mathrm{PM}$ and similar meteorological conditions, the case having lower $\mathrm{NO}_{y}$ concentrations $(0.4$ to 0.5 200 ppb on March 3 as compared to 0.7 to 0.8 ppb on February 16) was associated with considerably 201 higher absolute and relative factor loadings.

202 For the polluted cases shown in Figure S4, $\mathrm{NO}_{y}$ concentrations were variable between 203 and within cases, ranging from $1 \mathrm{ppb}$ up to $7 \mathrm{ppb}$. Larger sulfate mass concentrations (from left 204 to right) were associated with larger absolute and relative factor loadings, analogous to what was 205 observed for background cases. A comparison between March 3 and 13 (i.e., background and 206 polluted; Figure 4) shows that for similar sulfate concentrations but higher $\mathrm{NO}_{y}$ levels March 13 207 had considerably lower factor loadings. The case of February 9 (polluted) illustrates that the 
208 factor loadings did not exceed $0.4 \mu \mathrm{g} \mathrm{m}^{-3}$ and $f$ did not exceed 0.2 even at rarely high sulfate

209 concentrations in the wet season, reaching $0.9 \mu \mathrm{g} \mathrm{m}^{-3}$. This finding is attributed to the high NO

210 concentrations, as implied by $\mathrm{NO}_{y}$ concentrations of $3 \mathrm{ppb}$ and greater, that suppressed IEPOX

211 production.

212 These cases illustrate the possible wide range of observed sulfate mass concentrations

213 under background conditions, in great part overlapping with typical values of polluted

214 conditions. The cases also demonstrate that the trend in observed IEPOX-SOA factor loadings

215 and ratio $f$, both within each category (background or polluted conditions) and between them, can

216 be consistently explained by the roles that sulfate and NO exert on the production of IEPOX-

217 derived PM.

218 S4. Sulfate and particle acidity estimates in the context of field studies

219 The underlying relative importance of direct compared to indirect roles of sulfate on the

220 formation of IEPOX-derived PM is not well understood. Sulfate can play a direct role as a

221 nucleophile in the reaction of formation of organosulfates from IEPOX (Surratt et al., 2007b;

222 Nguyen et al., 2014). Organosulfates, however, are believed to constitute only a fraction of the

223 IEPOX-derived PM (Hu et al., 2015). Particle acidity, an indirect effect of sulfate, has been

224 shown to drive IEPOX-derived PM production in several lab studies (Surratt et al., 2007a;

225 Kuwata et al., 2015; Lewandowski et al., 2015). Nevertheless, the acidity effect observed in

226 laboratories is not as clearly observed in field studies, wherein $\mathrm{pH}$ estimates have typically been

227 employed as a proxy for acidity (Budisulistiorini et al., 2013; Lin et al., 2013; Worton et al.,

228 2013; Budisulistiorini et al., 2015; Xu et al., 2015). The present study corroborates those findings

229 and further argues that this apparent conflict can be reasoned by taking into account that both the

230 estimate and the end-use of $\mathrm{pH}$ may be problematic in the context of field studies. 
Firstly, a reliable estimate of $\mathrm{pH}$ is often hard to obtain. In the case of the present study,

232 some difficulties were imposed by data availability. Gas-phase measurements of $\mathrm{NH}_{3}$ or $\mathrm{HNO}_{3}$

233 were not available for performing "forward" mode calculations in thermodynamic models or gas-

234 particle phase partitioning calculations, which have been suggested as the best method to predict

$235 \mathrm{pH}$ (Hennigan et al., 2015). Co-located independent measurements of ion concentrations (e.g., by

236 chromatograph) were not available to confirm the ion balance obtained by AMS measurements

237 (Figure S7).

238 Bearing these caveats in mind, the analysis presented in the main text using sulfate as a

239 predictor for IEPOX-SOA was replicated here using $\mathrm{pH}$ in place of sulfate. Figure $\mathrm{S} 8$ is

240 analogous to Figure 6a. pH was estimated for IOP1 using AMS measurements of mass

241 concentrations of inorganic ions (sulfate, ammonium, nitrate, and chloride) and measurements of

242 RH and temperature. The E-AIM model II (Clegg et al., 1998) was employed. The final pH was

243 calculated taking into account both the inorganic water predicted by the model and the organic

244 water estimated from organic hygroscopicity $\kappa_{\text {org }}$ values (Thalman, in preparation), in a similar

245 fashion as described by Guo et al. (2015). Figure S8 shows that $\mathrm{pH}$, as calculated herein and for

246 the caveats herein, does not work well as a predictor for IEPOX-SOA factor loading. Figure S9

247 is analogous to Figure 7. Figure S9 shows that, although the overall dependencies on $\mathrm{NO}_{y}$ are

248 similar to analysis of the data by sulfate, the separation by $\mathrm{pH}$ yields groups that have less

249 distinct trends and ranges among them.

250 In addition to difficulties associated with generating accurate estimates of $\mathrm{pH}$, there is an

251 inconsistency between the timescales of estimated particle acidity and IEPOX-SOA factor

252 loadings that may preclude underlying correlations to emerge. The estimated $\mathrm{pH}$ makes use of

253 instantaneous $\mathrm{RH}$ and temperature values and is therefore an instantaneous estimate of $\mathrm{pH}$. They 
254 can change in timescales of 15 min or less giving mixing in the boundary layer, for example. On

255 the other hand, sulfate mass concentrations and IEPOX-SOA factor loadings are variables

256 representative of processes of longer time scales of hours and days. By not containing any

257 information on the particle acidity history in the past hours or days, the calculated instantaneous

$258 \mathrm{pH}$ may fail in capturing the true effect of acidity on the chemical formation of IEPOX-derived

259 PM. The RH cycling history of sulfate particles has been demonstrated to mediate the extent of

260 IEPOX-derived PM production (Wong et al., 2015). Moreover, sulfate, by being intrinsically

261 related to particle acidity and at the same time a species of congruent lifetime with secondary

262 organic material, may in fact be a better proxy to capture the history of particle acidity than

263 estimates of $\mathrm{pH}$. For these different reasons, sulfate rather than $\mathrm{pH}$ is used in the analysis herein.

264 The understanding, however, is that sulfate represents effects beyond those of the direct chemical

265 role of sulfate. In analogy to $\mathrm{pH}$, this discussion also extends to the use of sulfate rather than

266 instantaneous particle water content as the predictor of IEPOX-SOA factor loadings.

\section{S5. Five subsets of data based on $\mathrm{NO}_{y}$ concentrations}

268 The data subsets and fits shown in Figure 6 are shown in separate panels in Figure S5.

269 Once a trend of decreasing fit slope with increasing $\mathrm{NO}_{y}$ concentration was identified, the

270 number of data subsets was defined as the minimum necessary to have subsets of at least 100

271 data points (of a total of 888) to allow for robust statistics and that were also cohesive (as

272 measured by $R^{2}$ ) and non-redundant (i.e., of different fit lines).

273 The coloring by date in Figure S5 shows that there is no apparent correlation between

274 levels of $\mathrm{NO}_{y}$ concentration or goodness of fit with different time periods within IOP1.

275 Meteorological variables such as solar radiation, temperature, and RH (not shown) are also not

276 able to delineate any clear pattern in the data, either within or among groups. 
Although a linear bivariate statistical analysis for the IEPOX-SOA factor in sulfate and

$278 \mathrm{NO}_{y}$ concentrations at first appears attractive, the underlying chemical processes were not linear,

279 as reflected in the relationship between IEPOX-derived PM and $\mathrm{NO}_{y}$ concentrations. Moreover,

280 sulfate and $\mathrm{NO}_{y}$ concentrations were not independent variables. For these reasons, a linear

281 bivariate analysis is not appropriate, and a subset analysis was pursued instead.

\section{S6. Details and assumptions of the model}

The solution to the differential Equation 1 is as follows:

$$
M(t)=\frac{\alpha_{P} k_{P}}{\alpha_{L} k_{L}}+e^{\alpha_{L} k_{L} t}\left(M_{0}-\frac{\alpha_{P} k_{P}}{\alpha_{L} k_{L}}\right)
$$

285 for which the subscript 0 indicates initial (background) conditions, i.e., immediately before the

286 airmass passes over Manaus. For the transport from Manaus to T3, $t=\tau_{t r}$, and the variable $M$

287 represents the IEPOX-derived PM mass concentrations at T3.

The zero-order production rate coefficient $k_{P}$ and the first-order loss rate coefficient $k_{L}$

289 are lumped parameters representative of several production and loss processes, respectively. A

290 first assumption is that they are constant over the course of four hours. In hand with that

291 assumption, a constant boundary layer height throughout the integration time is assumed. The $\tau$

292 values represent the time required under afternoon conditions to significantly affect the IEPOX-

293 derived PM mass concentration by the corresponding processes. For afternoon time periods,

294 observations show that $d M / d t>0$ over tropical forests in the absence of pollution (Chen et al.,

295 2009; Chen et al., 2015). The parameter $\tau_{P}$, corresponding to a first order process, therefore

296 represents an instantaneous quantity in the transient system. For simplicity of presentation, $\tau_{P}$ is

297 defined in reference to $M_{0}$, although defining it in relation to $M_{b g}$ or $M_{p o l}$ does not alter the main

298 conclusions presented herein. 
In terms of loss processes, represented by the rate coefficient $k_{L}$, IEPOX-derived PM may

300 be lost by three main mechanisms: heterogeneous oxidation against $\mathrm{OH}$, condensed-phase

301 reactions, and dry deposition. The lifetime of IEPOX-derived PM against heterogeneous

302 oxidation is estimated at around two weeks for an $\mathrm{OH}$ concentration of $10^{6}$ molecules $\mathrm{cm}^{-3}(\mathrm{Hu}$ et

303 al., 2016). Lifetime of IEPOX products against particle-phase reactions has not yet been reported

304 but is expected to be at least several days. A value of one week is used here. The lifetime of PM

305 against deposition is on the order of a week. The overall loss process is then approximated in the

306 model as the sum of these three processes, which leads to an estimate of overall loss rate

307 coefficient $k_{L}=0.015 \mathrm{~h}^{-1}$ (overall characteristic time of 2.8 days).

308 In respect to wet deposition along the track from Manaus to the T3 site, strong convection

309 imports background regional air, and for this reason strong wet deposition is mathematically

310 equivalent in the model developed herein to a trajectory that does not pass over Manaus, i.e.,

311 background conditions. Weak wet deposition represents a mixing of polluted and background air

312 masses, giving rise to intermediate $\mathrm{NO}_{y}$ concentrations. Entrainment on the plume edges as well

313 as with the free troposphere is mathematically similar to wet deposition in the model framework.

314 Thus entrainment and wet deposition, without directly contributing to $k_{L}$, are indirectly

315 incorporated in the developed model based on their effects on $\mathrm{NO}_{y}$ concentration.

316 In terms of production processes, represented by the rate coefficient $k_{P}$, IEPOX-derived

317 PM is produced by multigenerational chemistry of isoprene photooxidation and reactive uptake.

318 Model Case 1 investigated the sensitivity of pollution enhancement ratio and absolute mass

319 concentration of IEPOX-derived PM to its production rate coefficient. After constrained by

320 observations, the estimated interval for $k_{P}$ was $[0.07,0.13] \mu \mathrm{g} \mathrm{m}^{-3} \mathrm{~h}^{-1}$. In addition, values of $k_{P}>$

$3210.2 \mu \mathrm{g} \mathrm{m}^{-3} \mathrm{~h}^{-1}$ are unlikely given the rare observation $(<1 \%)$ of $M_{b g}>1 \mu \mathrm{g} \mathrm{m} \mathrm{m}^{-3}$. 
The obtained range can be compared to estimates of total production rate of organic

323 material from diameter growth rates. Firstly, a relative production rate of 1:3 for IEPOX-derived

324 PM to total organic PM is assumed based on the following. IEPOX-derived PM is estimated to

325 contribute $34 \%$ on average to total organic PM in central Amazonia under background

326 conditions (Chen et al., 2015). For assumptions of equal first order loss rate coefficients for all

327 organic material, a mass concentration ratio of 1:3 for IEPOX-derived PM to total organic

328 material implies a ratio of 1:3 in their production rate coefficients $k_{P}$. As a consequence, the

329 estimated range for total organic material is $[0.21,0.39] \mu \mathrm{g} \mathrm{m}^{-3} \mathrm{~h}^{-1}$. For the estimate of organic

330 material production based on growth rates, an average growth rate of $10 \mathrm{~nm} \mathrm{~h}^{-1}$ (Kulmala et al.,

3312004 ) is assumed. Further assumptions are a range of particle number concentration of 500 to

$3321000 \mathrm{~cm}^{-3}$ and of initial diameter of 20 to $100 \mathrm{~nm}$, typical of background conditions in the

333 Amazon. The obtained range of organic material production from growth rate estimates is

334 therefore 0.02 to $0.32 \mu \mathrm{g} \mathrm{m}^{-3} \mathrm{~h}^{-1}$, which is comparable to the range constrained by the model.

335 In terms of the influence of Manaus plume on the production and loss processes, the

336 following assumptions were made. The acceleration of the oxidant cycle in the plume implies

337 that $\alpha_{L}>1$. Under plume conditions, $\mathrm{OH}$ concentrations observed at the $\mathrm{T} 3$ site increased by a

338 factor of three compared to background conditions (Martin et al., 2017; Kim, in preparation). A

339 proportional increase in the loss rate of IEPOX-derived PM by OH heterogeneous chemistry in

340 the plume is expected. While the $\mathrm{OH}$ loss mechanism (of characteristic time of two weeks) is

341 accelerated by three fold in the plume, dry deposition and condensed phase reactions (both of

342 assumed characteristic times of a week) are held constant. As a result, the overall loss rate is

343 enhanced by two fold, i.e., $\alpha_{L}=2$ is assumed. 
344 Concerning the production enhancement factor, the interception of ISOPOO radicals by

$345 \mathrm{NO}$ in the pollution plume as well as the faster consumption of intermediate gas-phase species by

346 the enhanced $\mathrm{OH}$ and $\mathrm{O}_{3}$ concentrations implies $\alpha_{P}<1$. The assumption is that the production of

347 IEPOX almost halts in the plume, and $\alpha_{P}=0.1$. This assumption is supported by measured gas-

348 phase concentrations of ISOPOOH at the T3 site, which dropped by $90 \%$ when $\mathrm{NO}_{y}$

349 concentrations increased from $0.5 \mathrm{ppb}$ to $2 \mathrm{ppb}$ (Liu et al., 2016). This observation and the

350 associated model assumption are a reflection of the lifetimes of the chemical species discussed:

351 in contrast to the abovementioned lifetimes on order of a week for organic particle material

352 against loss processes, the lifetimes of the gaseous species are significantly shorter. Isoprene and

353 ISOPOOH have a lifetime on the order of a few hours (Eddingsaas et al., 2010; St. Clair et al.,

354 2015), and IEPOX has a lifetime of a few hours to a day for an $\mathrm{OH}$ concentration of $10^{6}$

355 molecules $\mathrm{cm}^{-3}$ (Jacobs et al., 2013; Bates et al., 2014). 


\section{Supplementary References}

Bateman, A. P., Nizkorodov, S. A., Laskin, J., and Laskin, A.: Photolytic processing of secondary organic aerosols dissolved in cloud droplets, Phys. Chem. Chem. Phys., 13, 12199-12212, 2011, 10.1039/C1CP20526A.

Bates, K. H., Crounse, J. D., St. Clair, J. M., Bennett, N. B., Nguyen, T. B., Seinfeld, J. H., Stoltz, B. M., and Wennberg, P. O.: Gas phase production and loss of isoprene epoxydiols, J. Phys. Chem. A, 118, 1237-1246, 2014, 10.1021/jp4107958.

Budisulistiorini, S. H., Canagaratna, M. R., Croteau, P. L., Marth, W. J., Baumann, K., Edgerton, E. S., Shaw, S. L., Knipping, E. M., Worsnop, D. R., Jayne, J. T., Gold, A., and Surratt, J. D.: Real-time continuous characterization of secondary organic aerosol derived from isoprene epoxydiols in downtown Atlanta, Georgia, using the Aerodyne Aerosol Chemical Speciation Monitor, Environ. Sci. Technol., 47, 5686-5694, 2013, 10.1021/es400023n.

Budisulistiorini, S. H., Li, X., Bairai, S. T., Renfro, J., Liu, Y., Liu, Y. J., McKinney, K. A., Martin, S. T., McNeill, V. F., Pye, H. O. T., Nenes, A., Neff, M. E., Stone, E. A., Mueller, S., Knote, C., Shaw, S. L., Zhang, Z., Gold, A., and Surratt, J. D.: Examining the effects of anthropogenic emissions on isoprene-derived secondary organic aerosol formation during the 2013 Southern Oxidant and Aerosol Study (SOAS) at the Look Rock, Tennessee ground site, Atmos. Chem. Phys., 15, 8871-8888, 2015, 10.5194/acp15-8871-2015.

Canagaratna, M. R., Jayne, J. T., Jimenez, J. L., Allan, J. D., Alfarra, M. R., Zhang, Q., Onasch, T. B., Drewnick, F., Coe, H., Middlebrook, A., Delia, A., Williams, L. R., Trimborn, A. M., Northway, M. J., DeCarlo, P. F., Kolb, C. E., Davidovits, P., and Worsnop, D. R.: Chemical and microphysical characterization of ambient aerosols with the aerodyne 
aerosol mass spectrometer, Mass Spectrom. Rev., 26, 185-222, 2007, 10.1002/mas.20115.

Canagaratna, M. R., Jimenez, J. L., Kroll, J. H., Chen, Q., Kessler, S. H., Massoli, P., Hildebrandt Ruiz, L., Fortner, E., Williams, L. R., Wilson, K. R., Surratt, J. D., Donahue, N. M., Jayne, J. T., and Worsnop, D. R.: Elemental ratio measurements of organic compounds using aerosol mass spectrometry: characterization, improved calibration, and implications, Atmos. Chem. Phys., 15, 253-272, 2015, 10.5194/acp-15-253-2015.

Chen, Q., Farmer, D. K., Schneider, J., Zorn, S. R., Heald, C. L., Karl, T. G., Guenther, A., Allan, J. D., Robinson, N., Coe, H., Kimmel, J. R., Pauliquevis, T., Borrmann, S., Pöschl, U., Andreae, M. O., Artaxo, P., Jimenez, J. L., and Martin, S. T.: Mass spectral characterization of submicron biogenic organic particles in the Amazon Basin, Geophys. Res. Lett., 36, L20806, 2009, 10.1029/2009GL039880.

Chen, Q., Farmer, D. K., Rizzo, L. V., Pauliquevis, T., Kuwata, M., Karl, T. G., Guenther, A., Allan, J. D., Coe, H., Andreae, M. O., Pöschl, U., Jimenez, J. L., Artaxo, P., and Martin, S. T.: Submicron particle mass concentrations and sources in the Amazonian wet season (AMAZE-08), Atmos. Chem. Phys., 15, 3687-3701, 2015, 10.5194/acp-15-3687-2015.

Clegg, S. L., Brimblecombe, P., and Wexler, A. S.: Thermodynamic model of the system $\mathrm{H}^{+}-$ $\mathrm{NH}_{4}{ }^{+}-\mathrm{SO}_{4}{ }^{2-}-\mathrm{NO}_{3}{ }^{-}-\mathrm{H}_{2} \mathrm{O}$ at tropospheric temperatures, J. Phys. Chem. A, 102, 2137-2154, 1998, 10.1021/jp973042r.

de Sá, S. S.: Anthropogenic emissions affect the sources and composition of submicron particulate matter in central Amazonia in the wet season, in preparation.

DeCarlo, P. F., Kimmel, J. R., Trimborn, A., Northway, M. J., Jayne, J. T., Aiken, A. C., Gonin, M., Fuhrer, K., Horvath, T., Docherty, K. S., Worsnop, D. R., and Jimenez, J. L.: Field- 
deployable, high-resolution, time-of-flight aerosol mass spectrometer, Anal. Chem., 78, 8281-8289, 2006, 10.1021/ac061249n.

Eddingsaas, N. C., VanderVelde, D. G., and Wennberg, P. O.: Kinetics and products of the acidcatalyzed ring-opening of atmospherically relevant butyl epoxy alcohols, J. Phys. Chem. A, 114, 8106-8113, 2010, 10.1021/jp103907c.

Epstein, S. A., Blair, S. L., and Nizkorodov, S. A.: Direct photolysis of $\alpha$-pinene ozonolysis secondary organic aerosol: effect on particle mass and peroxide content, Environ. Sci. Technol., 48, 11251-11258, 2014, 10.1021/es502350u.

Guo, H., Xu, L., Bougiatioti, A., Cerully, K. M., Capps, S. L., Hite Jr, J. R., Carlton, A. G., Lee, S. H., Bergin, M. H., Ng, N. L., Nenes, A., and Weber, R. J.: Fine-particle water and pH in the southeastern United States, Atmos. Chem. Phys, 15, 5211-5228, 2015, 10.5194/acp-15-5211-2015

Hu, W. W., Campuzano-Jost, P., Palm, B. B., Day, D. A., Ortega, A. M., Hayes, P. L., Krechmer, J. E., Chen, Q., Kuwata, M., Liu, Y. J., de Sá, S. S., McKinney, K., Martin, S. T., Hu, M., Budisulistiorini, S. H., Riva, M., Surratt, J. D., St. Clair, J. M., Isaacman-Van Wertz, G., Yee, L. D., Goldstein, A. H., Carbone, S., Brito, J., Artaxo, P., de Gouw, J. A., Koss, A., Wisthaler, A., Mikoviny, T., Karl, T., Kaser, L., Jud, W., Hansel, A., Docherty, K. S., Alexander, M. L., Robinson, N. H., Coe, H., Allan, J. D., Canagaratna, M. R., Paulot, F., and Jimenez, J. L.: Characterization of a real-time tracer for isoprene epoxydiols-derived secondary organic aerosol (IEPOX-SOA) from aerosol mass spectrometer measurements, Atmos. Chem. Phys., 15, 11807-11833, 2015, 10.5194/acp15-11807-2015. 
Hu, W. W., Palm, B., Day, D., Campuzano-Jost, P., Krechmer, J., Peng, Z., De Sá, S. S., Martin, S. T., Alexander, M. L., Baumann, K., Hacker, L., Kiendler-Scharr, A., Koss, A., De Gouw, J., Goldstein, A. H., Seco, R., Sjostedt, S., Park, J.-H., Guenther, A., Kim, S., Canonaco, F., Prevot, A., Brune, W., and Jimenez, J. L.: Long lifetime of ambient isoprene epoxydiols-derived Secondary Organic Aerosol (IEPOX-SOA) against OH oxidation and evaporation, Atmos. Chem. Phys. Disc., 2016, doi: 10.5194/acp-2016-418. Isaacman-VanWertz, G. and Sueper, D.: TERN: TAG ExploreR and iNtegration https://sites.google.com/site/terninigor/.

Isaacman-VanWertz, G., Yee, L. D., Kreisberg, N. M., Wernis, R., Moss, J. A., Hering, S. V., de Sá, S. S., Martin, S. T., Alexander, M. L., Palm, B. B., Hu, W., Campuzano-Jost, P., Day, D. A., Jimenez, J. L., Riva, M., Surratt, J. D., Viegas, J., Manzi, A., Edgerton, E., Baumann, K., Souza, R., Artaxo, P., and Goldstein, A. H.: Ambient Gas-Particle Partitioning of Tracers for Biogenic Oxidation, Env. Sci. Technol., 2016, 10.1021/acs.est.6b01674.

Isaacman, G., Kreisberg, N., Yee, L., Worton, D., Chan, A., Moss, J., Hering, S., and Goldstein, A.: Online derivatization for hourly measurements of gas-and particle-phase semi-volatile oxygenated organic compounds by thermal desorption aerosol gas chromatography (SVTAG), Atmos. Meas. Tech., 7, 4417-4429, 2014, 10.5194/amt-7-4417-2014.

Jacobs, M. I., Darer, A. I., and Elrod, M. J.: Rate constants and products of the OH reaction with isoprene-derived epoxides, Environ. Sci. Technol., 47, 12868-12876, 2013, 10.1021/es403340g.

Jaoui, M., Kleindienst, T., Lewandowski, M., Offenberg, J., and Edney, E.: Identification and quantification of aerosol polar oxygenated compounds bearing carboxylic or hydroxyl 
groups. 2. Organic tracer compounds from monoterpenes, Environ. Sci. Technol., 39, 5661-5673, 2005, 10.1021/es048111b.

Jimenez, J. L., Canagaratna, M. R., Donahue, N. M., Prevot, A. S. H., Zhang, Q., Kroll, J. H., DeCarlo, P. F., Allan, J. D., Coe, H., Ng, N. L., Aiken, A. C., Docherty, K. S., Ulbrich, I. M., Grieshop, A. P., Robinson, A. L., Duplissy, J., Smith, J. D., Wilson, K. R., Lanz, V. A., Hueglin, C., Sun, Y. L., Tian, J., Laaksonen, A., Raatikainen, T., Rautiainen, J., Vaattovaara, P., Ehn, M., Kulmala, M., Tomlinson, J. M., Collins, D. R., Cubison, M. J., Dunlea, J., Huffman, J. A., Onasch, T. B., Alfarra, M. R., Williams, P. I., Bower, K., Kondo, Y., Schneider, J., Drewnick, F., Borrmann, S., Weimer, S., Demerjian, K., Salcedo, D., Cottrell, L., Griffin, R., Takami, A., Miyoshi, T., Hatakeyama, S., Shimono, A., Sun, J. Y., Zhang, Y. M., Dzepina, K., Kimmel, J. R., Sueper, D., Jayne, J. T., Herndon, S. C., Trimborn, A. M., Williams, L. R., Wood, E. C., Middlebrook, A. M., Kolb, C. E., Baltensperger, U., and Worsnop, D. R.: Evolution of organic aerosols in the atmosphere, Science, 326, 1525-1529, 2009, 10.1126/science.1180353.

Kim, S., in preparation.

Kroll, J. H., Smith, J. D., Che, D. L., Kessler, S. H., Worsnop, D. R., and Wilson, K. R.: Measurement of fragmentation and functionalization pathways in the heterogeneous oxidation of oxidized organic aerosol, Phys. Chem. Chem. Phys., 11, 8005-8014, 2009, 10.1039/B905289E.

Kulmala, M., Vehkamäki, H., Petäjä, T., Dal Maso, M., Lauri, A., Kerminen, V. M., Birmili, W., and McMurry, P. H.: Formation and growth rates of ultrafine atmospheric particles: a review of observations, J. Aerosol Sci., 35, 143-176, 2004, http://dx.doi.org/10.1016/j.jaerosci.2003.10.003. 
Kuwata, M., Zorn, S. R., and Martin, S. T.: Using elemental ratios to predict the density of organic material composed of carbon, hydrogen, and oxygen, Environ. Sci. Technol., 46, 787-794, 2011, 10.1021/es202525q.

Kuwata, M., Liu, Y., McKinney, K., and Martin, S. T.: Physical state and acidity of inorganic sulfate can regulate the production of secondary organic material from isoprene photooxidation products, Phys. Chem. Chem. Phys., 17, 5670-5678, 2015, 10.1039/C4CP04942J.

Lewandowski, M., Jaoui, M., Offenberg, J., Krug, J., and Kleindienst, T.: Atmospheric oxidation of isoprene and 1, 3-butadiene: influence of aerosol acidity and relative humidity on secondary organic aerosol, Atmos. Chem. Phys., 15, 3773-3783, 2015, 10.5194/acp-15$3773-2015$.

Lin, Y.-H., Knipping, E., Edgerton, E., Shaw, S., and Surratt, J. D.: Investigating the influences of $\mathrm{SO}_{2}$ and $\mathrm{NH}_{3}$ levels on isoprene-derived secondary organic aerosol formation using conditional sampling approaches, Atmos. Chem. Phys., 13, 8457-8470, 2013, 10.5194/acp-13-8457-2013.

Liu, Y., Kuwata, M., Strick, B. F., Geiger, F. M., Thomson, R. J., McKinney, K. A., and Martin, S. T.: Uptake of epoxydiol isomers accounts for half of the particle-phase material produced from isoprene photooxidation via the $\mathrm{HO}_{2}$ pathway, Environ. Sci. Technol., 49, 250-258, 2015, 10.1021/es5034298.

Liu, Y., Brito, J., Dorris, M. R., Rivera-Rios, J. C., Seco, R., Bates, K. H., Artaxo, P., Duvoisin, S., Keutsch, F. N., Kim, S., Goldstein, A. H., Guenther, A. B., Manzi, A. O., Souza, R. A. F., Springston, S. R., Watson, T. B., McKinney, K. A., and Martin, S. T.: Isoprene 
photochemistry over the Amazon rain forest, Proc. Natl. Acad. Sci. USA, 113, 61256130, 2016, 10.1073/pnas.1524136113.

Lopez-Hilfiker, F. D., Mohr, C., D’Ambro, E. L., Lutz, A., Riedel, T. P., Gaston, C. J., Iyer, S., Zhang, Z., Gold, A., Surratt, J. D., Lee, B. H., Kurten, T., Hu, W. W., Jimenez, J., Hallquist, M., and Thornton, J. A.: Molecular composition and volatility of organic aerosol in the Southeastern US: implications for IEPOX derived SOA, Environ. Sci. Technol., 2200-2209, 2016, 10.1021/acs.est.5b04769.

Martin, S. T., Artaxo, P., Machado, L. A. T., Manzi, A. O., Souza, R. A. F., Schumacher, C., Wang, J., Andreae, M. O., Barbosa, H. M. J., Fan, J., Fisch, G., Goldstein, A. H., Guenther, A., Jimenez, J. L., Pöschl, U., Silva Dias, M. A., Smith, J. N., and Wendisch, M.: Introduction: observations and modeling of the green ocean Amazon (GoAmazon2014/5), Atmos. Chem. Phys., 16, 4785-4797, 2016, 10.5194/acp-16-47852016.

Martin, S. T., Artaxo, P., Machado, L., Manzi, A. O., Souza, R. A. F., Schumacher, C., Wang, J., Biscaro, T., Brito, J., Calheiros, A., Jardine, K., Medeiros, A., Portela, B., Sá, S. S. d., Adachi, K., Aiken, A. C., Albrecht, R., Alexander, L., Andreae, M. O., Barbosa, H. M. J., Buseck, P., Chand, D., Comstock, J. M., Day, D. A., Dubey, M., Fan, J., Fast, J., Fisch, G., Fortner, E., Giangrande, S., Gilles, M., Goldstein, A. H., Guenther, A., Hubbe, J., Jensen, M., Jimenez, J. L., Keutsch, F. N., Kim, S., Kuang, C., Laskin, A., McKinney, K., Mei, F., Miller, M., Nascimento, R., Pauliquevis, T., Pekour, M., Peres, J., Petäjä, T., Pöhlker, C., Pöschl, U., Rizzo, L., Schmid, B., Shilling, J. E., Dias, M. A. S., Smith, J. N., Tomlinson, J. M., Tóta, J., and Wendisch, M.: The Green ocean Amazon Experiment 
(GoAmazon2014/5) observes pollution affecting gases, aerosols, clouds, and rainfall over the rain forest, B. Am. Meteorol. Soc., 2017, doi:10.1175/BAMS-D-15-00221.1.

Ng, N., Canagaratna, M., Jimenez, J., Chhabra, P., Seinfeld, J., and Worsnop, D.: Changes in organic aerosol composition with aging inferred from aerosol mass spectra, Atmos. Chem. Phys., 11, 6465-6474, 2011, 10.5194/acp-11-6465-2011.

Nguyen, T. B., Coggon, M. M., Bates, K. H., Zhang, X., Schwantes, R. H., Schilling, K. A., Loza, C. L., Flagan, R. C., Wennberg, P. O., and Seinfeld, J. H.: Organic aerosol formation from the reactive uptake of isoprene epoxydiols (IEPOX) onto non-acidified inorganic seeds, Atmos. Chem. Phys., 14, 3497-3510, 2014, 10.5194/acp-14-3497-2014.

Riva, M., Budisulistiorini, S. H., Chen, Y., Zhang, Z., D’Ambro, E. L., Zhang, X., Gold, A., Turpin, B. J., Thornton, J. A., Canagaratna, M. R., and Surratt, J. D.: Chemical characterization of secondary organic aerosol from oxidation of isoprene hydroxyhydroperoxides, Environ. Sci. Technol., 2016, 10.1021/acs.est.6b02511.

St. Clair, J. M., Rivera-Rios, J. C., Crounse, J. D., Knap, H. C., Bates, K. H., Teng, A. P., Jørgensen, S., Kjaergaard, H. G., Keutsch, F. N., and Wennberg, P. O.: Kinetics and products of the reaction of the first-generation isoprene hydroxy hydroperoxide (ISOPOOH) with OH, J. Phys. Chem. A, 2015, 10.1021/acs.jpca.5b06532.

Surratt, J. D., Lewandowski, M., Offenberg, J. H., Jaoui, M., Kleindienst, T. E., Edney, E. O., and Seinfeld, J. H.: Effect of acidity on secondary organic aerosol formation from isoprene, Environ. Sci. Technol., 41, 5363-5369, 2007a, 10.1021/es0704176.

Surratt, J. D., Kroll, J. H., Kleindienst, T. E., Edney, E. O., Claeys, M., Sorooshian, A., Ng, N. L., Offenberg, J. H., Lewandowski, M., Jaoui, M., Flagan, R. C., and Seinfeld, J. H.: 
Evidence for organosulfates in secondary organic aerosol, Environ. Sci. Technol., 41, 517-527, 2007b, 10.1021/es062081q.

Thalman, R., in preparation.

Ulbrich, I., Canagaratna, M., Zhang, Q., Worsnop, D., and Jimenez, J.: Interpretation of organic components from Positive Matrix Factorization of aerosol mass spectrometric data, Atmos. Chem. Phys., 9, 2891-2918, 2009, 10.5194/acp-9-2891-2009.

Wong, J. P., Lee, A. K., and Abbatt, J. P.: Impacts of Sulfate Seed Acidity and Water Content on Isoprene Secondary Organic Aerosol Formation, Environ. Sci. Technol., 49, 1321513221, 2015, 10.1021/acs.est.5b02686.

Worton, D. R., Surratt, J. D., LaFranchi, B. W., Chan, A. W. H., Zhao, Y., Weber, R. J., Park, J.H., Gilman, J. B., de Gouw, J., Park, C., Schade, G., Beaver, M., Clair, J. M. S., Crounse, J., Wennberg, P., Wolfe, G. M., Harrold, S., Thornton, J. A., Farmer, D. K., Docherty, K. S., Cubison, M. J., Jimenez, J.-L., Frossard, A. A., Russell, L. M., Kristensen, K., Glasius, M., Mao, J., Ren, X., Brune, W., Browne, E. C., Pusede, S. E., Cohen, R. C., Seinfeld, J. H., and Goldstein, A. H.: Observational insights into aerosol formation from isoprene, Environ. Sci. Technol., 47, 11403-11413, 2013, 10.1021/es4011064.

Xu, L., Guo, H., Boyd, C. M., Klein, M., Bougiatioti, A., Cerully, K. M., Hite, J. R., IsaacmanVanWertz, G., Kreisberg, N. M., Knote, C., Olson, K., Koss, A., Goldstein, A. H., Hering, S. V., de Gouw, J., Baumann, K., Lee, S.-H., Nenes, A., Weber, R. J., and Ng, N. L.: Effects of anthropogenic emissions on aerosol formation from isoprene and monoterpenes in the southeastern United States, Proc. Natl. Acad. Sci. USA, 112, 37-42, 2015, 10.1073/pnas.1417609112. 
Zhang, Q., Alfarra, M. R., Worsnop, D. R., Allan, J. D., Coe, H., Canagaratna, M. R., and Jimenez, J. L.: Deconvolution and quantification of hydrocarbon-like and oxygenated organic aerosols based on aerosol mass spectrometry, Environ. Sci. Technol., 39, 49384952, 2005, 10.1021/es0485681.

Zhang, X., Smith, K. A., Worsnop, D. R., Jimenez, J. L., Jayne, J. T., Kolb, C. E., Morris, J., and Davidovits, P.: Numerical characterization of particle beam collimation: part II integrated aerodynamic-lens-nozzle system, Aerosol Sci. Technol., 38, 619-638, 2004, 10.1080/02786820490479833. 


\section{List of Supplementary Figures}

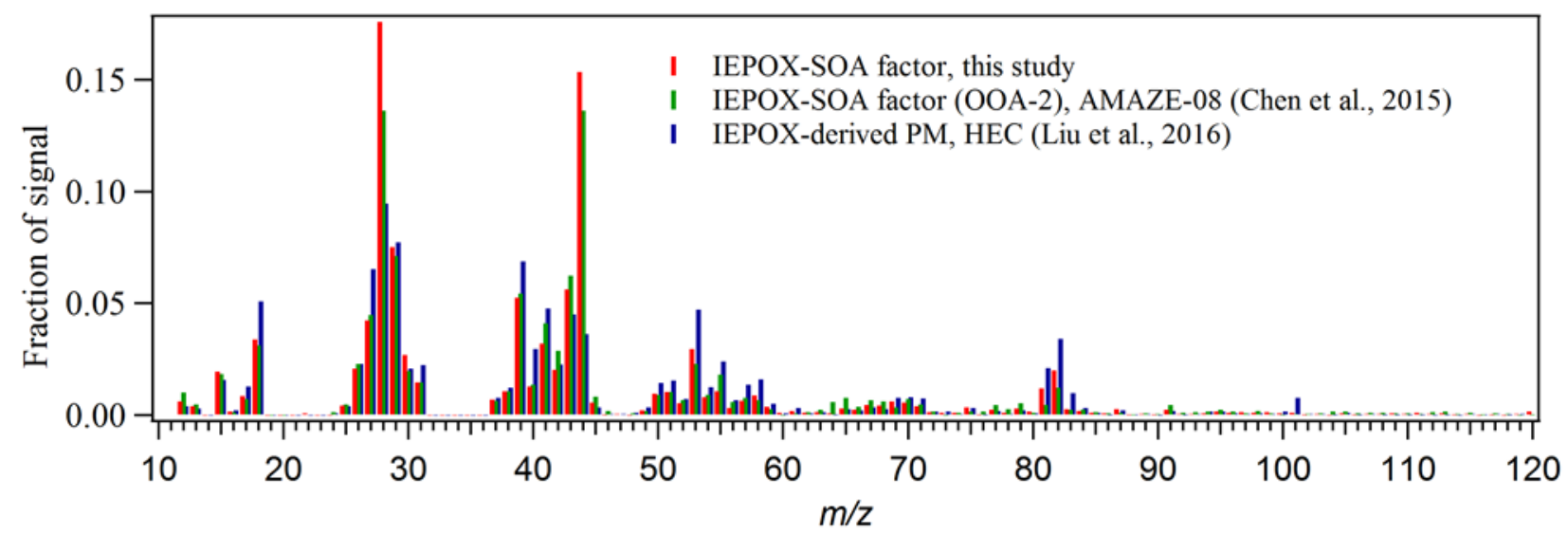

Figure S1. Profile of the IEPOX-SOA factor resolved by PMF analysis of the time series of AMS organic mass spectra collected in the wet season of 2014 (IOP1) at the T3 site (red), and in the wet season of 2008 (green) as part of AMAZE-08 experiment at the T0t site (Chen et al., 2015). Also plotted is the mass spectrum of secondary organic material produced in the Harvard Environmental Chamber from $\beta$-IEPOX photooxidation onto acidic ammonium sulfate seed particles under $\mathrm{HO}_{2}$-dominant conditions and $\mathrm{RH}<5 \%$ (blue) (Liu et al., 2015). Pearson correlation coefficients $R$ between the PMF factor of this study and the other spectra were: $R=$ 0.99 for the AMAZE-08 PMF factor, $R=0.81$ for the chamber spectrum with all ions included, and $R=0.95$ for the chamber spectrum with $\mathrm{m} / \mathrm{z} 44$ and 28 excluded. 
(a)

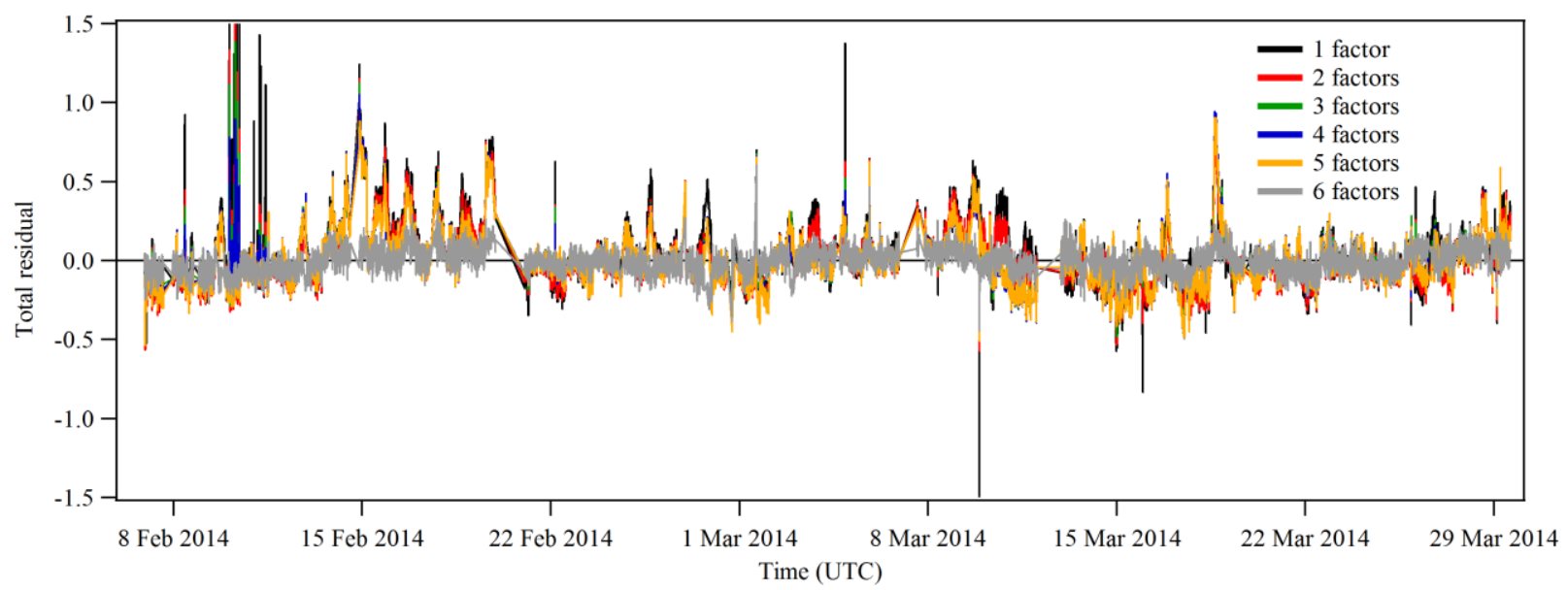

(b)

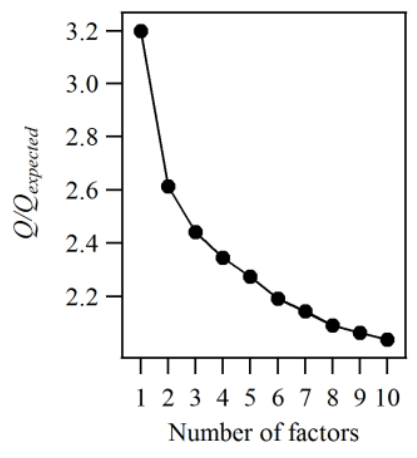

(c)

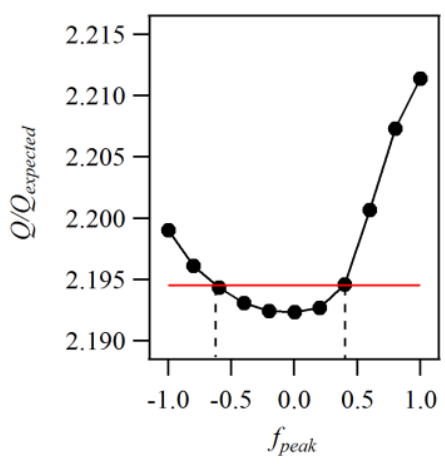

(d)

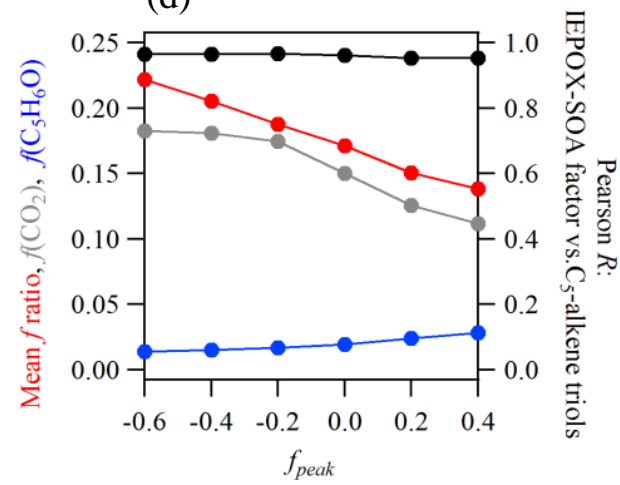

Figure S2. (a) Time series of total ion residuals of PMF solutions from one to six factors, (b) Dependence of the quality-of-fit parameter $Q / Q_{\text {expected }}$ on the number of factors for $f_{\text {peak }}=0$, (c) Dependence of the quality-of-fit parameter $Q / Q_{\text {expected }}$ on $f_{\text {peak }}$ for number of factors $=6$. The red line represents $Q / Q_{\text {expected }}$ that exceeds in $0.1 \%$ the minimum value at $f_{\text {peak }}=0$. This limit determines the range of plausible $f_{\text {peak }}$ values as indicated by the dashed black lines, (d) For the six-factor solution, dependence on the $f_{\text {peak }}$ parameter of the Pearson correlation coefficient $R$ between the IEPOX-SOA factor loadings and independently measured $\mathrm{C}_{5}$-alkene triols (on the right vertical axis), the mean $f$ ratio of IEPOX-SOA factor loading to total organic PM mass concentration, and the relative intensities $f\left(\mathrm{CO}_{2}\right)$ and $f\left(\mathrm{C}_{5} \mathrm{H}_{6} \mathrm{O}\right)$ of the ions $\mathrm{CO}_{2}{ }^{+}$and $\mathrm{C}_{5} \mathrm{H}_{6} \mathrm{O}^{+}$, respectively (on the left vertical axis). 
(a) 3 March 2014

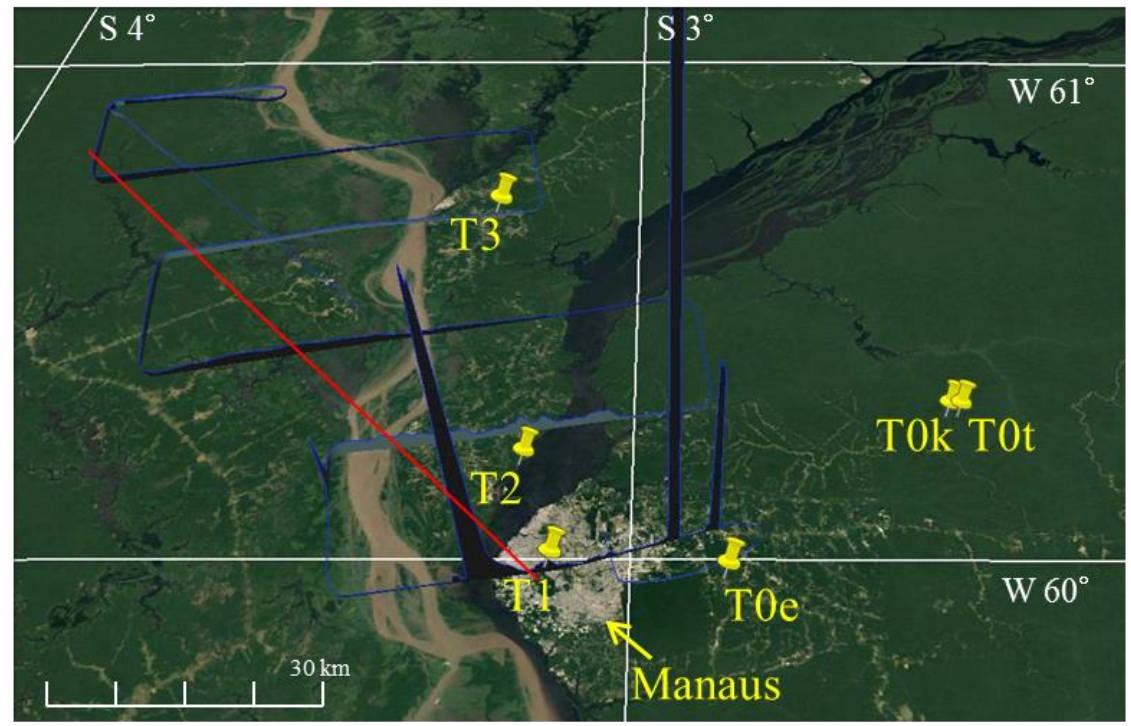

(b) 13 March 2014

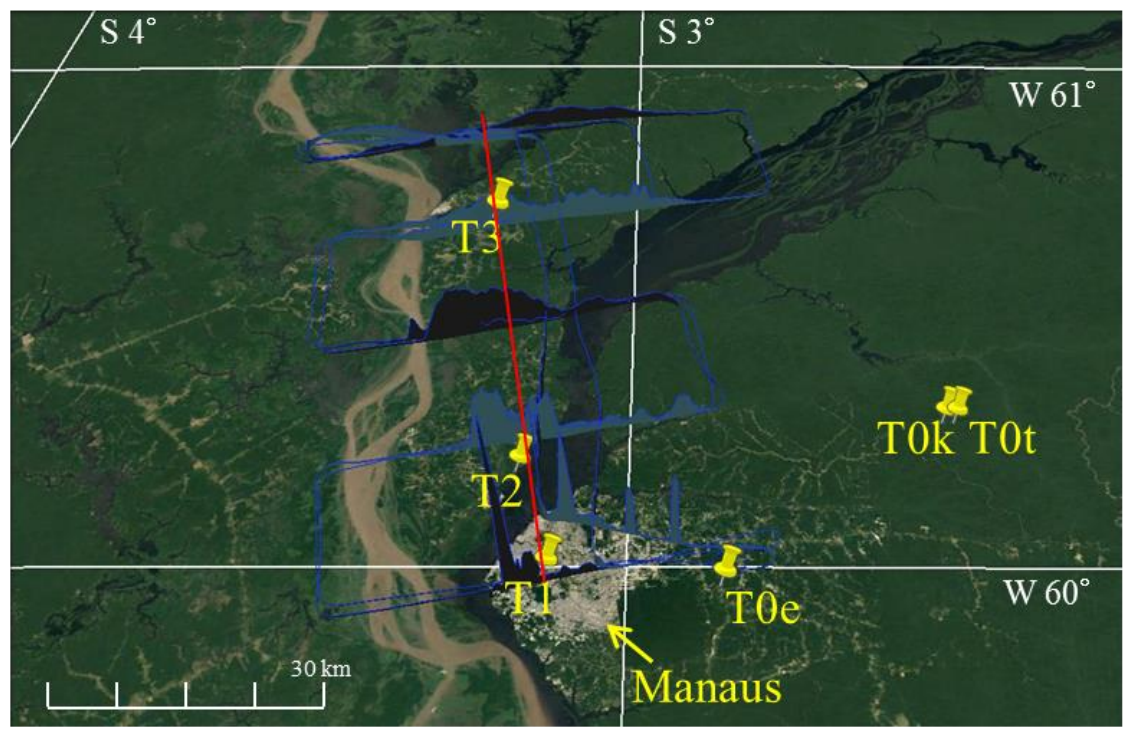

Figure S3. Visualization of the Manaus pollution plume for (a) March 3, 2014, 17:45 - 19:26 UTC, and (b) March 13, 2014, 14:14 - 17:21 UTC. The direction and extent of the plume observed within the boundary layer in the Manaus environs by the G-1 aircraft is represented by plotting $\mathrm{NO}_{y}$ concentrations on a vertical axis $(0.13$ to $369 \mathrm{ppb}$ on March 3 and 0.10 to $75 \mathrm{ppb}$ on March 13). The red lines guide the eye through the central axis of the plume. An image of land cover is in the horizontal plane. Yellow pins indicate the locations of some of the GoAmazon2014/5 research sites, including T3 (Martin et al., 2016). 

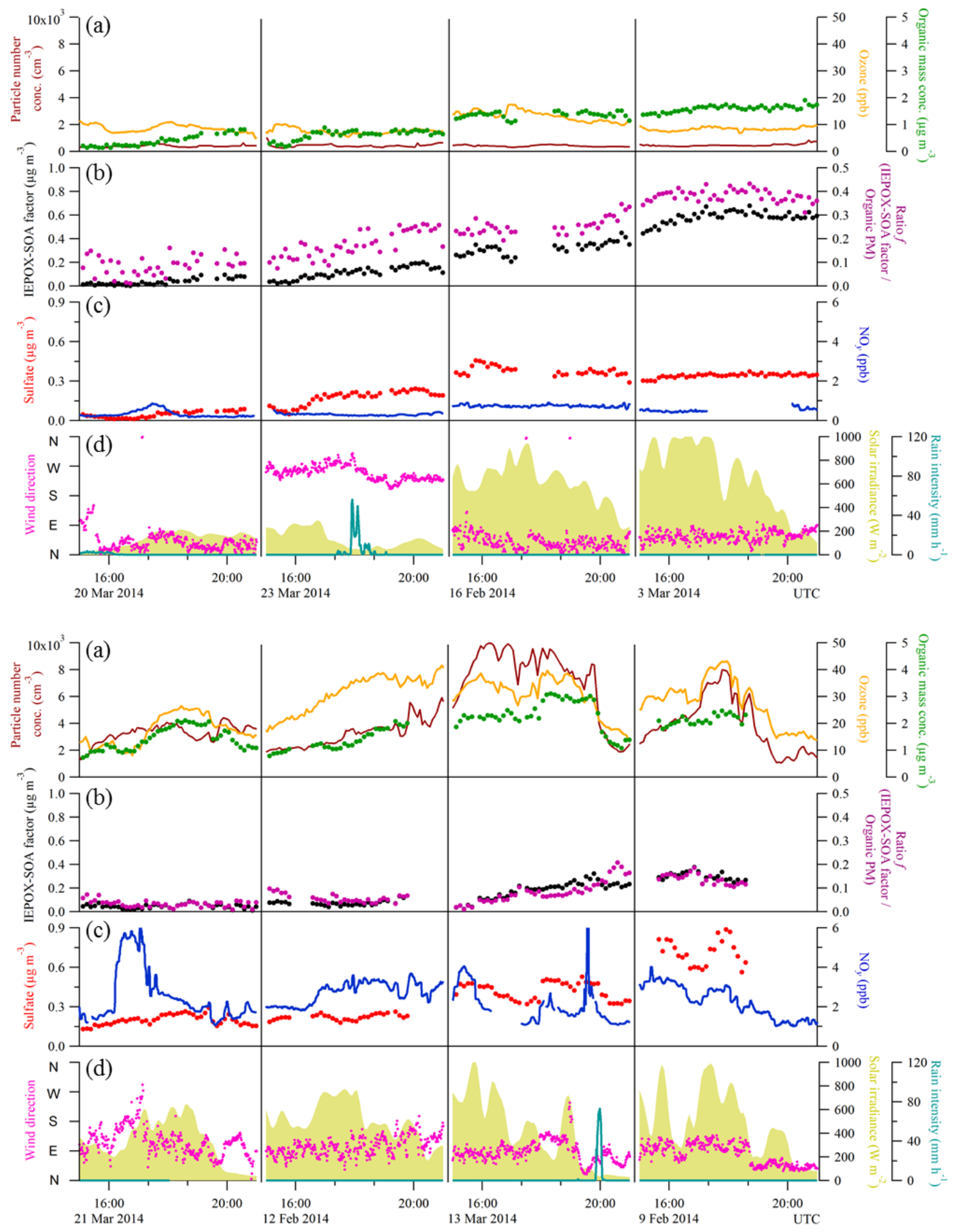

Figure S4. Selected cases of data sets collected during background and polluted conditions (top and bottom panels, respectively) as observed during afternoons at the T3 site. 


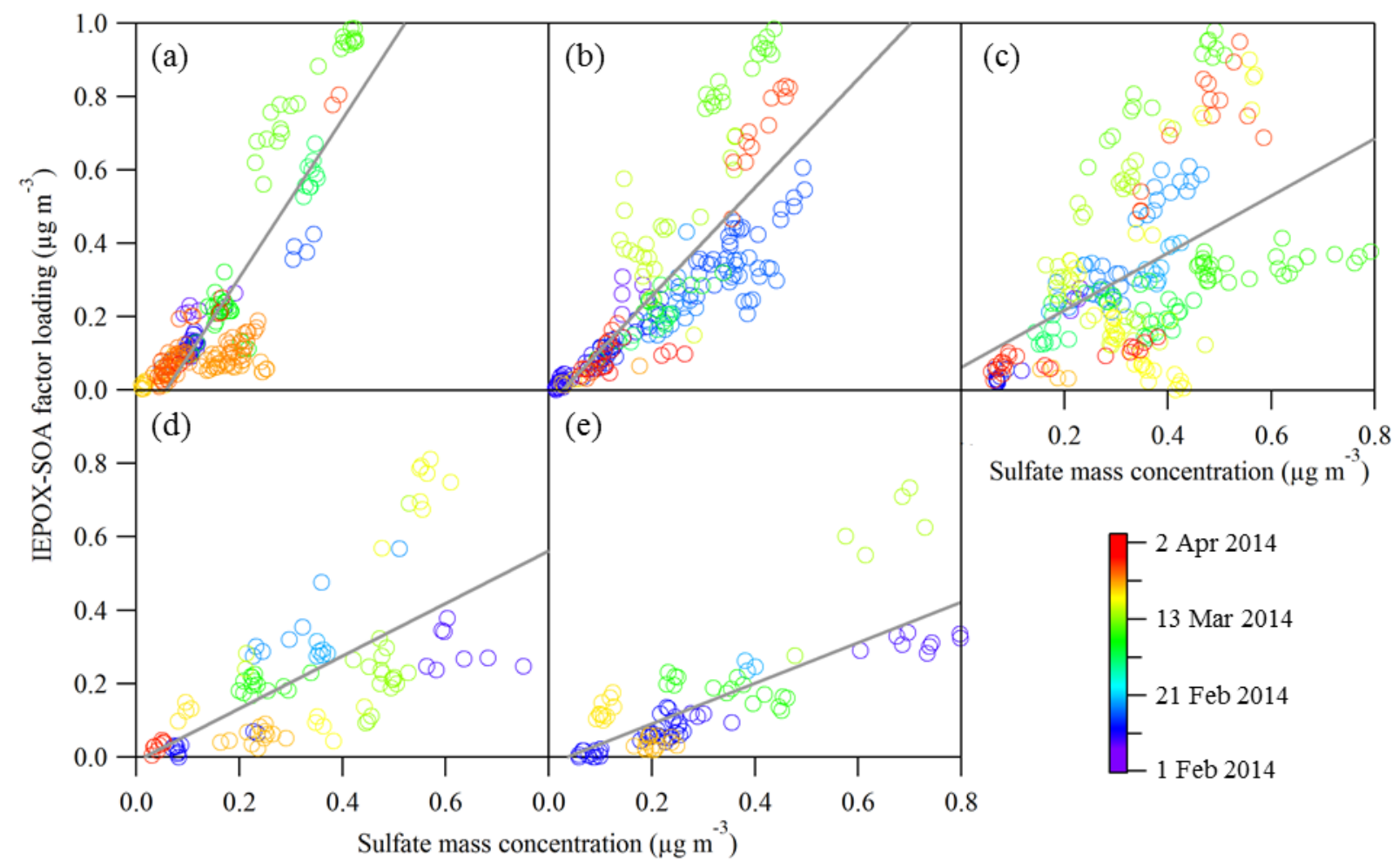

Figure S5. Scatter plots of sulfate mass concentration and IEPOX-SOA factor loading for local afternoon (12:00-16:00 local time; 16:00-20:00 UTC) for five different ranges of $\mathrm{NO}_{y}$ concentrations. Panels a-e correspond to groups labeled 1-5 according to Table 1. Table 1 presents the parameters of the six least-squares linear fits represented by the lines in the figure. Data is colored by date. 


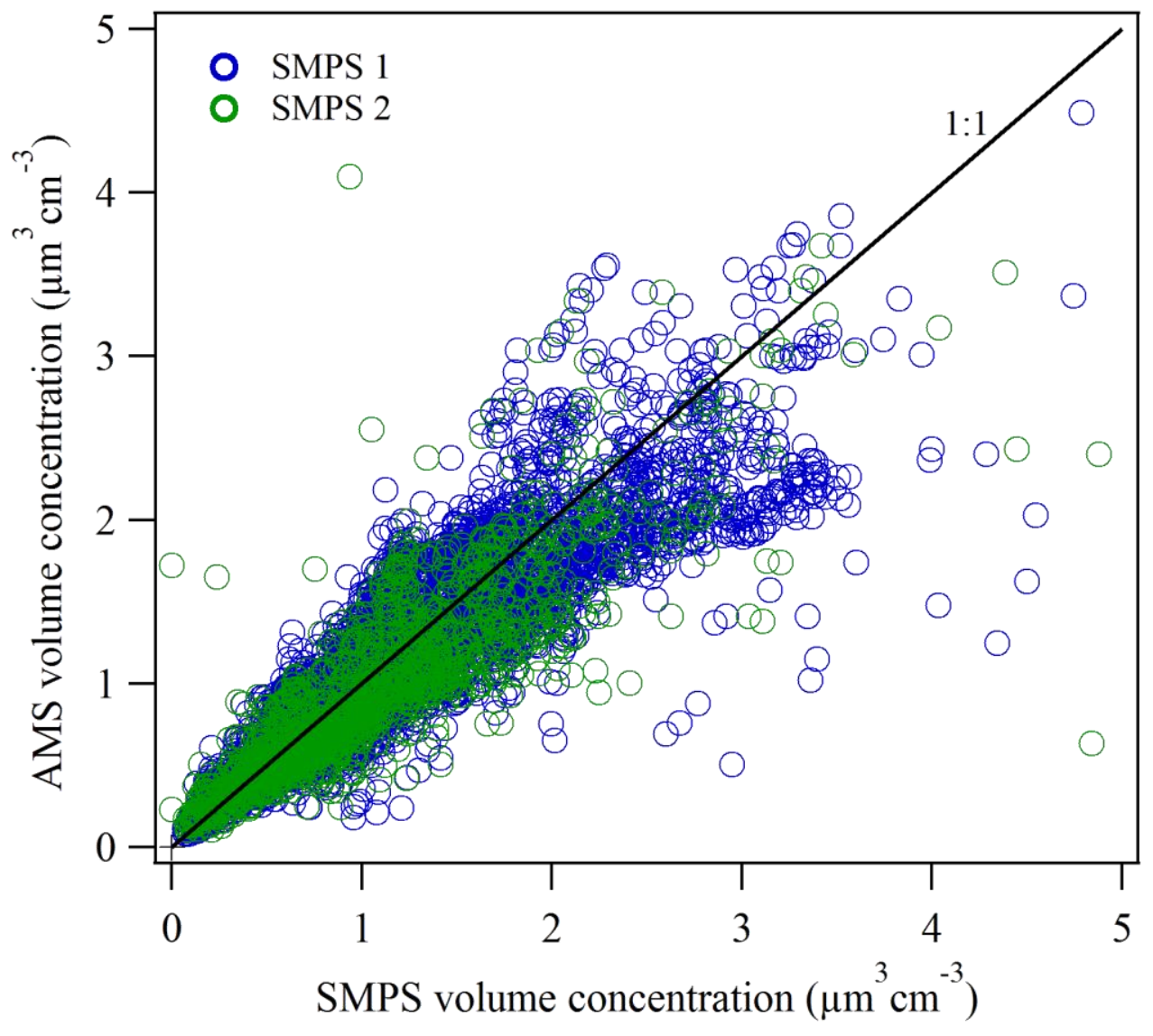

Figure S6. Scatter plot of AMS PM volume concentrations and SMPS PM volume concentrations. SMPS1 measured particles having mobility diameters of 10 to $461 \mathrm{~nm}$ from February 7 to March 28, 2014. SMPS2 measured particles having mobility diameters of 10 to $510 \mathrm{~nm}$ from February 24 to March 30. Material densities used in the calculation of AMS volume from AMS mass were based on a mixing rule for the five AMS-measured species. The material density of the organic component was calculated following the method of Kuwata et al. (2011) based on O:C and H:C values, which in turn were calculated following the method of Canagaratna et al. (2015). 


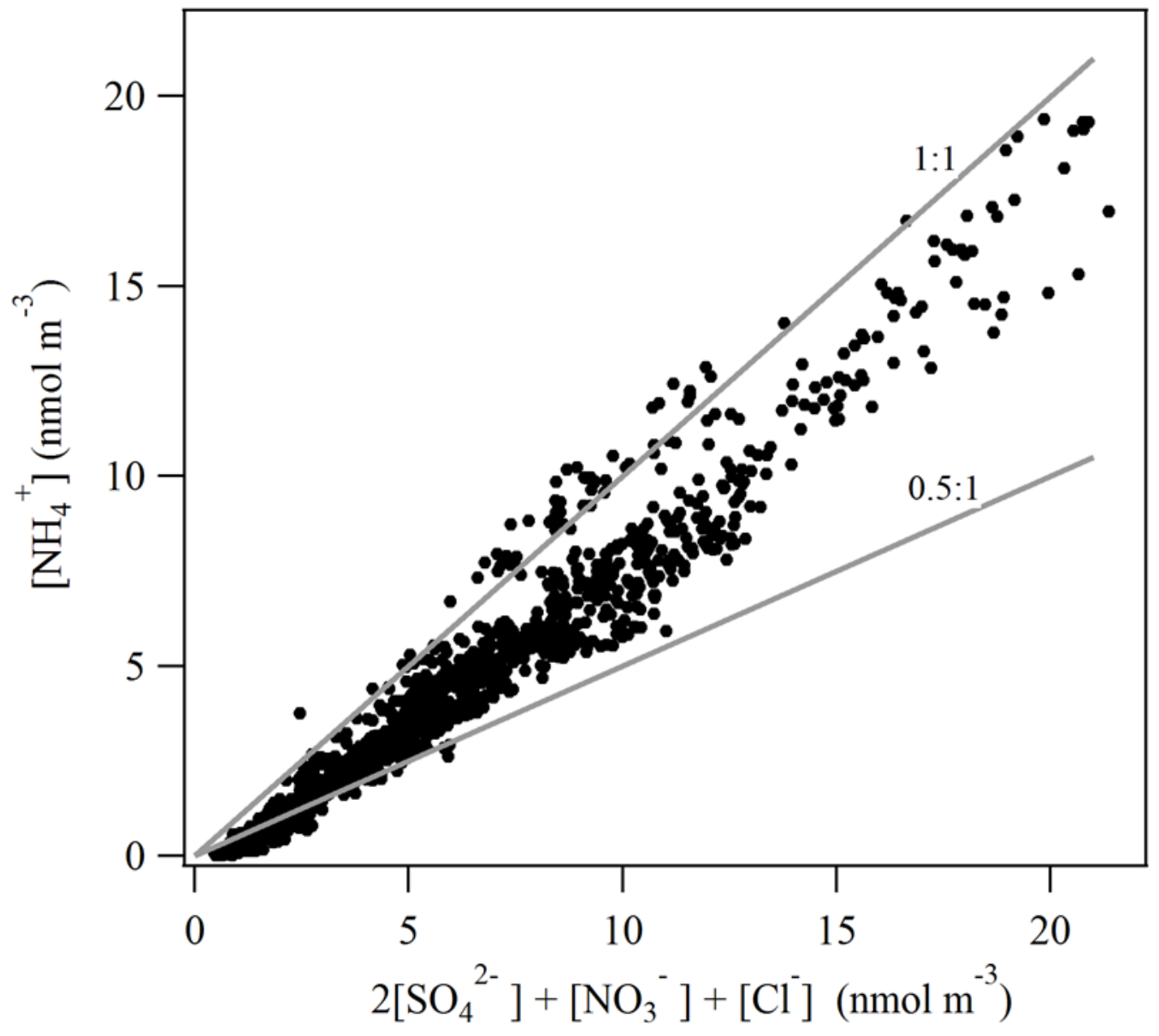

Figure S7. Ion balance for AMS measured species. A scatter plot is shown of mass concentrations of cations on the ordinate and of anions on the abscissa. Solid gray lines indicate relationships of $1: 1$ and 0.5:1. 


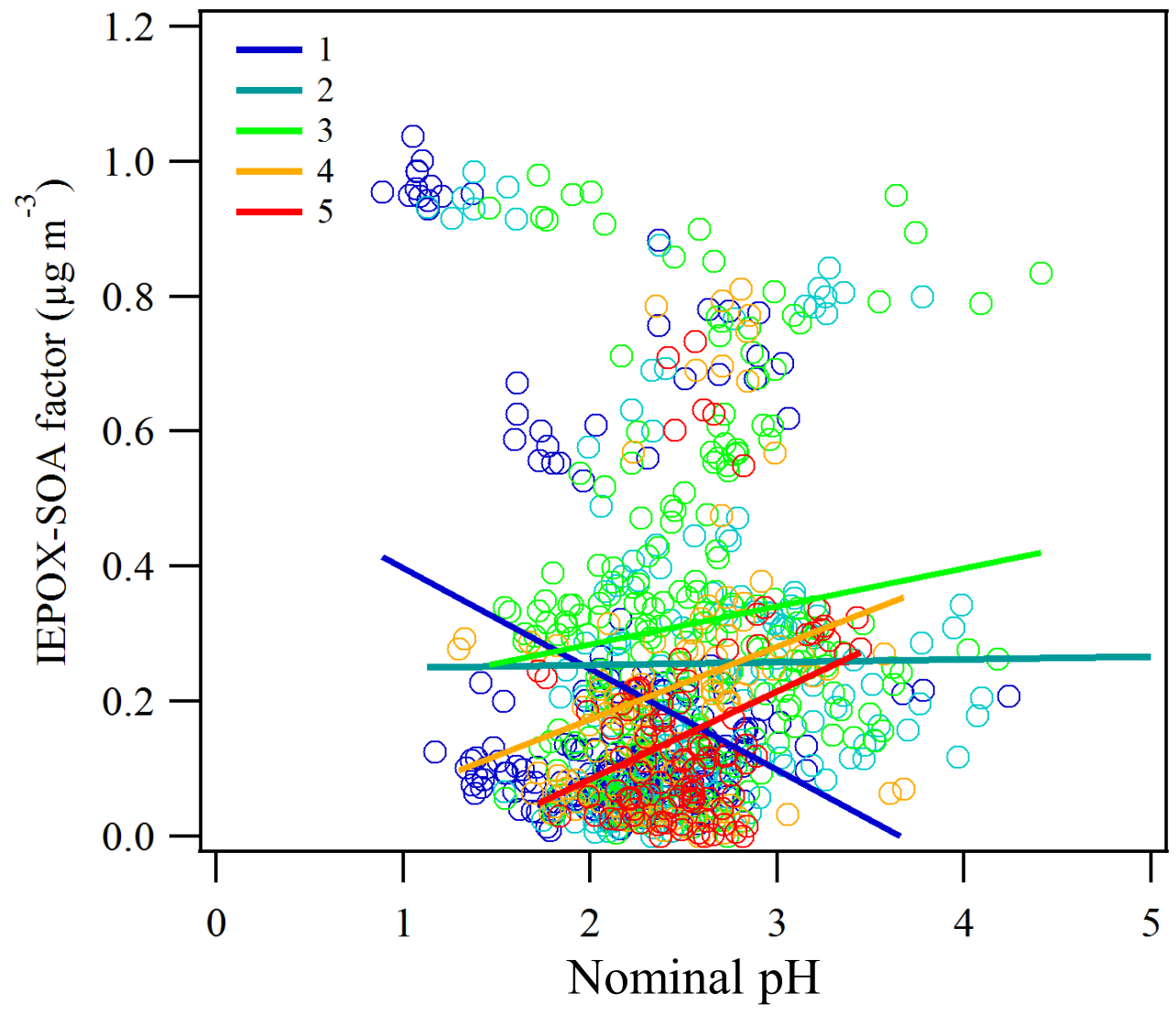

Figure S8. Scatter plot of estimated $\mathrm{pH}$ and IEPOX-SOA factor loading for local afternoon (12:00-16:00 local time; 16:00-20:00 UTC). The data sets were collected into five subsets, colored and labeled 1 to 5, based on $\mathrm{NO}_{y}$ concentration (analogous to analysis shown in Figure 6a). 


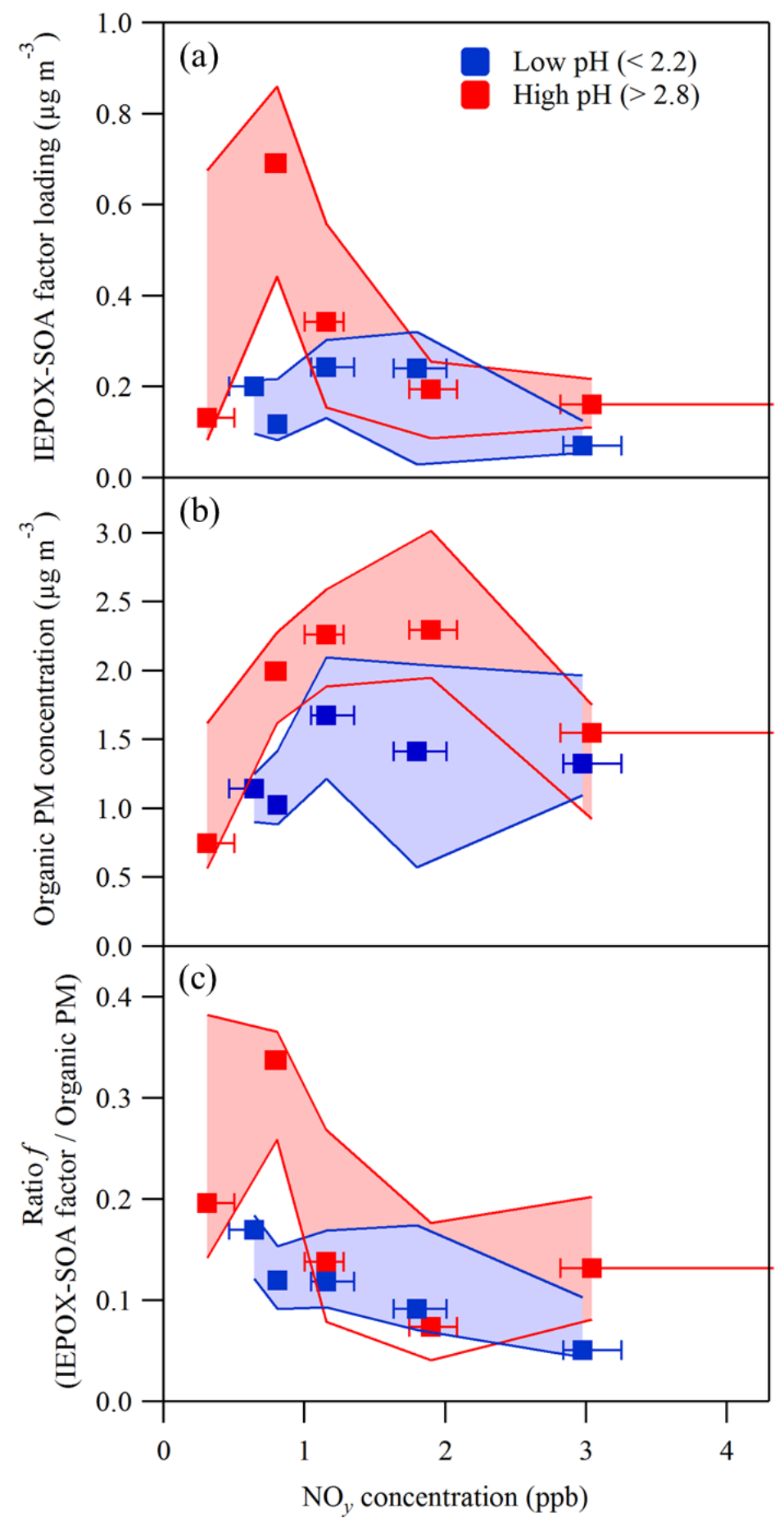

Figure S9. Dependence on $\mathrm{NO}_{y}$ concentration of (a) IEPOX-SOA factor loading, (b) organic mass concentration, and (c) the ratio $f$ of the IEPOX-SOA factor loading to the organic PM concentration. Data are segregated by low $(<2.2)$ and high $(>2.8) \mathrm{pH}$ and grouped into five levels of $\mathrm{NO}_{y}$ concentration (Figure 7). Squares represent medians of each group. Interquartile ranges are represented by whiskers along the abscissa and shading along the ordinate. The plotted data sets were recorded during local afternoon (12:00-16:00 local time; 16:00-20:00 UTC). 